\title{
Maintenance of Platelet Counts with Low Level QC Materials and the Change in P-LCR according to Hemolysis with XN-9000
}

\author{
Moon-Jung Shim ${ }^{1}$, Hyun-A Lee ${ }^{2}$ \\ ${ }^{1}$ Department of Clinical Laboratory Science, Ansan University, Ansan, Korea \\ ${ }^{2}$ Department of Laboratory Medicine, Korea University Medical Center, Ansan Hospital, Ansan, Korea
}

\section{XN-9000장비에서 Low Level QC물질에서의 혈소판 수 관리와 용혈에 따른 P-LCR의 변화}

\author{
심문정 ${ }^{1}$, 이현아 ${ }^{2}$ \\ ${ }^{1}$ 안산대학교 임상병리과, ${ }^{2}$ 고려대학교 안산병원 진단검사의학과
}

\begin{abstract}
The platelet count in clinical laboratories is essential for the diagnosis and treatment of hemostasis abnormalities, and accurate platelet counting in the low count range is of prime importance for deciding if a platelet transfusion is needed and for monitoring after chemotherapy. Quality control is designed to reduce and correct any deficiencies in the internal analytical process of a clinical laboratory prior to the release of patient results. Fragmented erythrocytes are the major confusing factors for platelet counting because of their similar size to platelets. The authors found that the low range QC values were out of 2SD with a Sysmex automatic analyzer in internal quality control process. Thus far, there has been little discussion on the relationship between hemolysis and the platelet parameters. Therefore, this study focused on the performance of automated platelet counts, including the PLT-F, the PLT-I, and PLT-O methods at the low platelet range using the low level QC materials and compared the 5 platelet parameters with the hemolyzed samples. The results showed that the CV was the smallest with PLT-F and P-LCR increased from 18.4 to $31.9 \%$ in the hemolysis samples. These results indicate that a more accurate estimation of the platelet counts can be achieved using the PLT-F method than the PLT-I method at the low platelet range. The use of the PLT-F system improves the confidence of results in low platelets samples in a routine hematology laboratory. The results suggest that P-LCR is a new parameter in assessing samples when the specimen is suspected of hemolysis and deterioration. Nevertheless, further studies will be needed to establish the relationship with P-LCR and hemolysis using human blood specimens.
\end{abstract}

Key words: Hemolysis, Platelet large cell ratio, platelet counting with fluorescence, Quality control, XN 9000

This is an Open Access article distributed under the terms of the Creative Commons Attribution Non-Commercial License (http://creativecommons.org/licenses/by-nc/4.0) which permits unrestricted non-commercial use, distribution, and reproduction in any medium, provided the original work is properly cited.

Copyright (C) 2018 The Korean Society for Clinical Laboratory Science. All rights reserved.
Corresponding author: Moon-Jung Shim Department of Clinical Laboratory Science, Ansan University, 155 Ansandaehak-ro, Sangrok-gu, Ansan 15328, Korea Tel: 82-31-400-6938

Fax: 82-31-363-7702

E-mail: mjshim@ansan.ac.kr

Received: October 29, 2018 Revised $1^{\text {st: }}$ November 13,2018 Revised $2^{\text {nd }}:$ November 22, 2018 Accepted: November 23, 2018 


\section{INTRODUCTION}

The assessment of the platelet count is essential for the diagnosis and monitoring of patients receiving intensive cytotoxic chemotherapy. Platelet counts less than $20.0 \times$ $10^{9} / \mathrm{L}$ are the critical decision-making level for platelet transfusion and an indicator of increased spontaneous bleeding risk [1, 2].

The routinely used Sysmex XE2100 analyzer is equipped with 2 platelet detection methods, the impedance method (PLT-I) and the optical method (PLT-O). In the majority of samples, platelets are accurately counted using PLT-I [3-5]. Sysmex XN-2000 (Sysmex, Kobe, Japan) provided a new method for platelet counting. PLT-F method is based on a fluorescent RNA staining dye which have a phenoxazine backbone. The XN-2000's PLT-F method was reported to estimate platelets in thrombocytopenic samples more accurately than dose the PLT-O method [6].

Quality control activities play an important part in assuring the quality of the clinical laboratory tests. Quality control material is usually run at the beginning of each shift, after an instrument is serviced, when reagent lots are changed, after calibration, and when patient's results seem inappropriate. In the presence of RBC fragmentation, a platelet histogram cannot be adequately drawn, and the indices cannot be recorded correctly. Thus, platelet indices have a limited use as an indicator for thrombocytopenia.

The platelet indices such as MPV (Mean Platelet Volume), PDW (Platelet Distribution Width), PCT (plateletcrit) and P-LCR (Platelet Large Cell-Ratio) are usually available as part of hematology outputs of many of the automated analyzers and provide some important information [7, 8]. Abnormal red blood cell with low volume, including microcytes, schistocytes and spherocytes have been reported to be the cause of spuriously high platelet counts. In case the patients undergoing chemotherapy, the deviations may be occurred by the presence of white blood cell fragments after apoptosis. In the Sysmex XN-2000 analyzer, PLT-I and RBCs are analyzed in the same channel and can be separated from each other by their different volume. As a result, abnormally small RBCs, such as microcytes and schistocytes, may be counted as platelets. The fragmented erythrocytes are the major confusing factors for platelet counting because of their similar size to platelets. Indeed, a subset of the fragmented erythrocytes occupied the same region as platelets and misidentified as platelet by the PLT-O method [9, 10]. And the Sysmex XN-9000, an automated hematology analyzer, provides a parameter that refers to the percentage of large platelets-platelet larger cell ratio (P-LCR). Among platelet indices, little is known about P-LCR, and how the hemolyzed sample influences on platelet indices has not fully been discussed and described in scientific articles. And we observed the low range platelet counts range material with Sysmex XN-9000 was out of 2SD with the automatic analyzer which is used routinely. This platelet counting method was impedance method. We observed that the QC data was unstable and tried to improve the problem.

This study focused on the performance of automated platelet counts, including the PLT-F, the PLT-I and PLT-O methods at the low platelet range using the low level QC materials and comparison the 5 platelet parameters with the hemolyzed samples.

\section{MATERIALS AND METHODS}

\section{Preparation of samples}

$\mathrm{XN}$ CHECK $^{\mathrm{TM}}$ was used in this study. XN CHECK $^{\mathrm{TM}}$ is used for control and calibration verification of Sysmex XN series analyzers and is an in-vitro diagnostic product that contains stabilized WBC, RBC, PLT, nRBC components in a preservative medium.

To examine how do the hemolyzed samples exert influence on the platelet count, the control materials were kept into the deep freezer (Thermo Fisher Scientific, Waltham, USA) and frozen at $-80^{\circ} \mathrm{C}$ for $2 \mathrm{~h}$. After thawing it, the samples were smeared and confirmed the hemolysis by examining the morphology (Figure 1). The RBC counts was decreased from $2.24 \times 10^{12} / \mathrm{L}$ to $1.75 \times 10^{12} / \mathrm{L}$ after hemolysis process. And we assumed that the samples after 
A

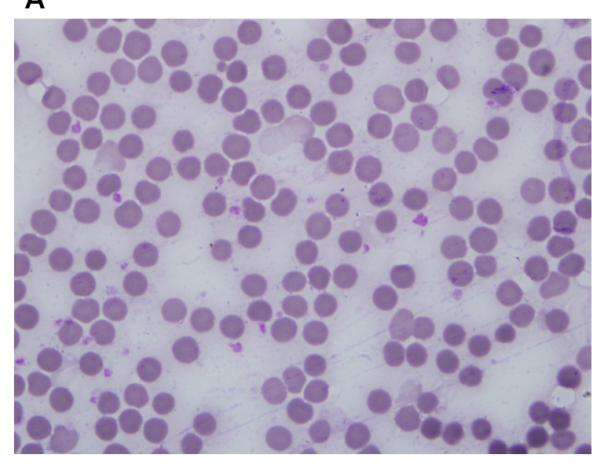

B

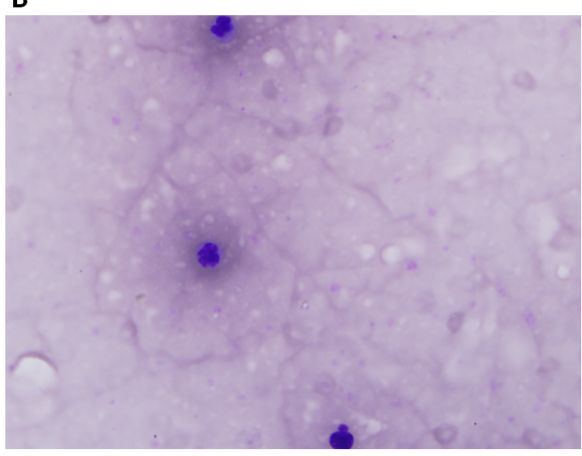

Figure 1. The microscopic results of XN CHECK material: (A) before hemolysis (B) after hemolysis $(\times 1,000)$.

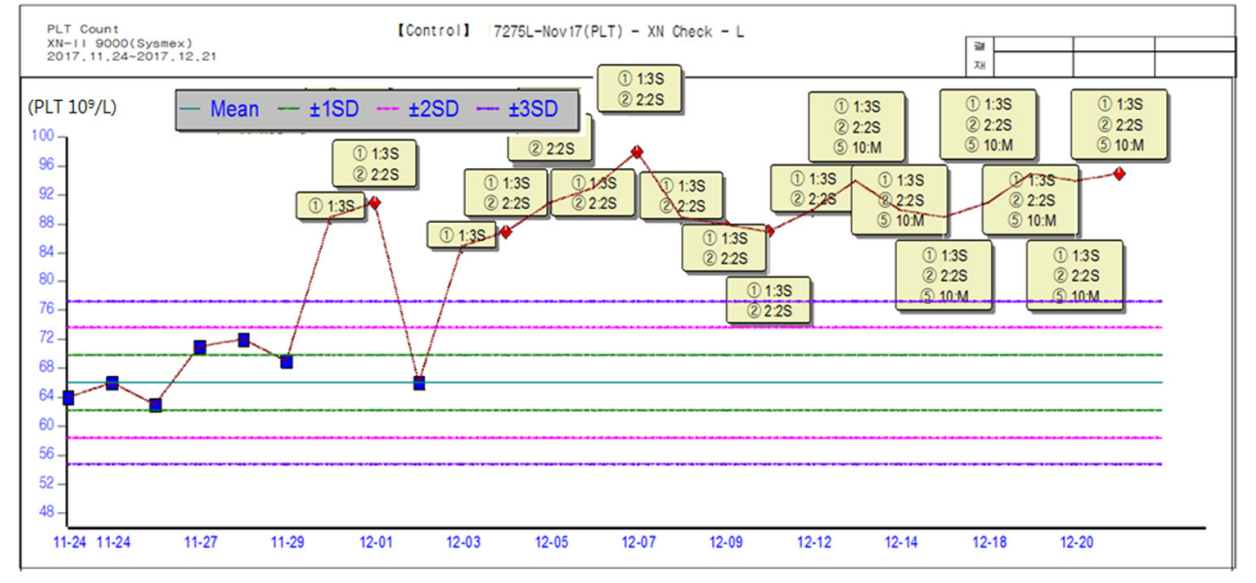

Figure 2. The internal $\mathrm{QC}$ results of platelet counts using the XN CHECK low QC materials with PLT-I system. PLT-I, impedance method of platelet counting. freezing were the $100 \%$ hemolyzed. Non-hemolysis sample is the original QC materials.

\section{The analysis of the difference in platelet counts between PLT-F, PLT-I, and PLT-O}

The low level QC materials were examined with the XN-9000 series (Sysmex, Kobe, Japan) using its three platelet-counting methods, PLT-F, PLT-I, PLT-O between 13 lots (Lot No. 61931101-81341101) respectively from April 5th and June 7th, 2018) 50 times per lot respectively. And we analyzed the 5- platelet parameter (MPV, PDW, PCT, P-LCR, PLT) at the low level materials according to the hemolysis. The P-LCR is the percentage of the platelet with size a more than $12 \mathrm{fL}$. And the QC materials were performed daily according to the manufacturer's instructions and coefficient of variation (CV) continuously measured two times was determined.

\section{Statistical analysis}

Statistical analysis was performed using the SPSS, PC Version 21.0 (SPSS, Chicago, USA) program. The differences in platelet counts between PLT-I, PLT-O, PLT-F system were analyzed for significance using one-way ANOVA. The statistical significance level was presented with 95\% confidence intervals $(P<0.05)$.

\section{RESULTS}

\section{The QC results of PLT-I and PLT- F system at low platelet counts range}

We experienced that the XN Check low level QC material was unstable when the XN-9000 series (Sysmex, Kobe, Japan) was introduced last year. After performing of internal quality control, the low range $\mathrm{QC}$ values were out of 2SD with PLT-I channel (Figure 2). To resolve the problem, the acceptable limits was reset. However, the 
problem remained unresolved. We reperformed the quality control with PLT-F channel at low range platelet count. The Figure 3 showed the comparison of QC result with PLT-I and PLT-F method. The repeat value was within acceptable limits with PLT-F and we confirmed the data was stable. This study suggest that it is necessary for creating the new folder of PLT-F when the low level QC material is performed.

\section{The comparison to the mean of platelet with PLT-I, PLT-O, PLT-F at XN CHECK low level materials}

The base on the experience of internal QC problem, the low level QC materials was examined with the XN-9000 series (Sysmex, Kobe, Japan) using its three plateletcounting methods, PLT-F, PLT-I, PLT-O between 13 lots from $5^{\text {th }}$ April to $7^{\text {th }}$ June, 2018. For low platelet counts, the mean of platelet counts was $90.25 \pm 8.81 \times 10^{9} / \mathrm{L}$ for PLT-I,
A

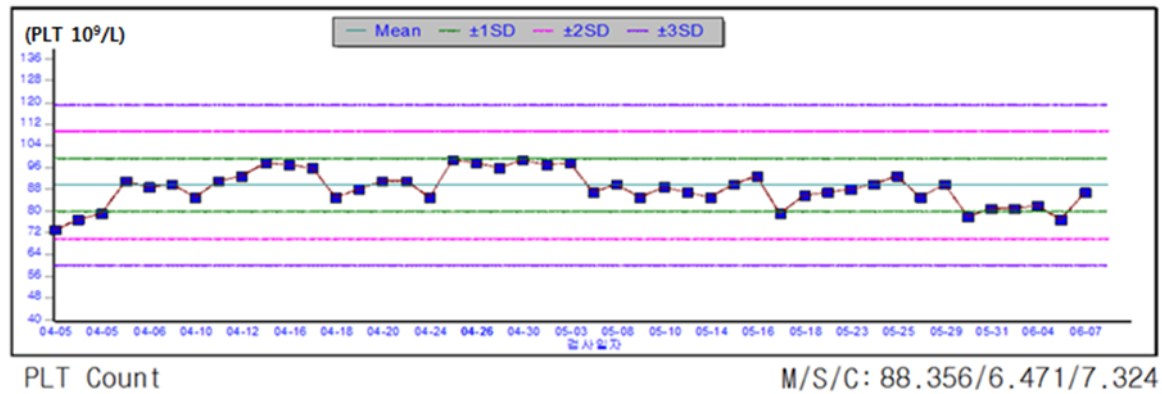

8078L-Apr 18 - XN Check - L

B

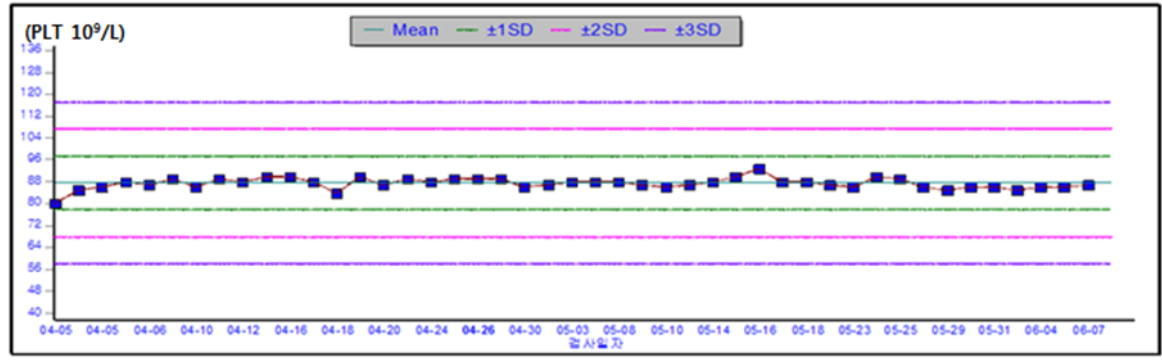

PLT-F Count

8078L-Apr 18 - XN Check - L
Figure 3. The comparison with the PLT-I (A) and PLT-F (B) methods of platelet counting using the XN CHECK low QC materials. M, mean; S, standard deviation; $C$, coefficient of variation (CV\%); PLT, platelet; PLT-I, impedance method of platelet counting; PLT-F, platelet counting with fluorescence.

Table 1. The comparison to the mean of platelet with PLT-I, PLT-O, PLT-F system at XN CHECK low materials

\begin{tabular}{|c|c|c|c|c|c|c|}
\hline \multirow{2}{*}{$\begin{array}{l}\text { Lot } \\
\text { No. }\end{array}$} & \multicolumn{2}{|c|}{ PLT-I } & \multicolumn{2}{|c|}{ PLT-O } & \multicolumn{2}{|c|}{ PLT-F } \\
\hline & $\mathrm{M} \pm \mathrm{SD}\left(10^{9} / \mathrm{L}\right)^{*}$ & CV (\%) & $\mathrm{M} \pm \mathrm{SD}\left(10^{9} / \mathrm{L}\right)^{\star}$ & CV (\%) & $\mathrm{M} \pm \mathrm{SD}\left(10^{9} / \mathrm{L}\right)^{\star}$ & CV (\%) \\
\hline 61931101 & $93.37 \pm 4.25$ & 4.56 & $105.96 \pm 5.75$ & 5.43 & $84.93 \pm 1.75$ & 2.06 \\
\hline 62491101 & $92.72 \pm 3.28$ & 3.54 & $105.83 \pm 5.85$ & 5.53 & $83.89 \pm 1.64$ & 1.96 \\
\hline 63051101 & $91.94 \pm 3.36$ & 3.66 & $99.70 \pm 3.62$ & 3.63 & $82.62 \pm 1.23$ & 1.49 \\
\hline 63611101 & $93.02 \pm 5.08$ & 5.46 & $102.29 \pm 4.75$ & 4.64 & $84.40 \pm 2.28$ & 2.70 \\
\hline 70511101 & $102.34 \pm 3.98$ & 3.89 & $109.76 \pm 5.21$ & 4.75 & $90.92 \pm 1.40$ & 1.54 \\
\hline 71071101 & $94.78 \pm 3.58$ & 3.78 & $105.08 \pm 3.96$ & 3.77 & $82.78 \pm 1.38$ & 1.66 \\
\hline 71631101 & $95.00 \pm 3.96$ & 4.17 & $104.77 \pm 3.74$ & 3.57 & $82.77 \pm 1.45$ & 1.75 \\
\hline 72191101 & $94.82 \pm 4.21$ & 4.44 & $104.39 \pm 4.39$ & 4.20 & $80.88 \pm 1.57$ & 1.95 \\
\hline 72751101 & $86.36 \pm 9.50$ & 11.00 & $96.57 \pm 4.05$ & 4.19 & $79.08 \pm 3.72$ & 4.70 \\
\hline 73311101 & $76.31 \pm 9.54$ & 12.50 & $94.08 \pm 4.15$ & 4.41 & $77.71 \pm 3.73$ & 4.80 \\
\hline 80221101 & $86.06 \pm 7.90$ & 9.18 & $105.67 \pm 3.80$ & 3.60 & $90.96 \pm 1.49$ & 1.64 \\
\hline 80781101 & $87.53 \pm 6.67$ & 7.62 & $105.24 \pm 4.52$ & 4.29 & $87.72 \pm 2.10$ & 2.39 \\
\hline 81341101 & $83.35 \pm 5.07$ & 6.09 & $105.27 \pm 4.22$ & 4.01 & $85.54 \pm 2.38$ & 2.78 \\
\hline
\end{tabular}

Abbreviations: M, mean; SD, standard deviation; CV, coefficient of variation; PLT-I, impedance method of platelet counting; PLT-O, optical method of platelet counting; PLT-F, platelet counting with fluorescence.

${ }^{*} P<0.01$. $P$-values were calculated by one-way ANOVA. 
$84.09 \pm 4.54 \times 10^{9} / \mathrm{L}$ for PLT-F and the CV of samples of the three different methods studied was in the range $7.3 \%$ for PLT-I, 2.35\% for PLT-F. The comparison of the three methods showed that the CV was the smallest with PLT-F. We confirmed that there are significantly the differences among the evaluated methods $(P<0.01)$. It could provide better precision and accuracy of analysis for low platelet counts (Table 1, Figure 4). In the present study, platelet counts measured using the PLT-F method were compared with those measured using the PLT-I method. We identified significantly higher accuracy in platelet counts when using the PLT-F method than PLT-O, PLT-I method in low platelet samples. The Sysmex PLT-F method in making appropriate clinical decisions in thrombocytopenic patients.

\section{The change of platelet parameters according to the hemolysis}

To confirm whether the PLT-F system could discriminate platelets from hemolyzed sample, we analyzed with two counting methods, PLT-F, PLT-I, and platelet parameter (PDW, MPV, P-LCR, PCT) in the low level QC materials (Table 2). We analyzed using the low level QC materials because the platelet counts were too high and out of AMR in hemolyzed normal and high QC materials. It is not thought that the accurate values of P-LCR and other platelet parameters were trusted. Figure 5 showed that the typical scattergram and histogram of platelet counts with PLT-F were changed according to hemolysis. It is thought that changes are due to fragmented RBC. At low level QC material, the platelet counts for non-hemolysis were $89 \times 10^{9} / \mathrm{L}$ and $82 \times 10^{9} / \mathrm{L}$ with PLT-I and PLT-F. However, for $100 \%$ hemolysis the platelet counts were increased with PLT-I system. We reconfirmed that platelet counts of PLT-F were less affected by hemolysis than PLT-I. In this result, P-LCR was increased from 18.4 to $31.9 \%$ after hemolysis (Table 2). A larger MPV is an indicator of in vivo platelet activation and it is increased in vascular diseases as myocardial and cerebral infarction. These results indicate that a more accurate estimation of platelet counts can be achieved using the PLT-F method than the PLT-I method. We suggest that P-LCR is a new parameter in assessing the hemolysis samples. However, the further investigation is needed to establish the relationship with P-LCR and hemolysis.

Table 2. The comparison of platelet parameters after hemolysis in XN Check low level QC materials

\begin{tabular}{lccc}
\hline & & \multicolumn{2}{c}{ LOW LEVEL QC MATERIALS } \\
\cline { 3 - 4 } & & Non hemo & $100 \%$ hemo \\
\hline PLT-I & $10^{9} / \mathrm{L}$ & 81.00 & 158.00 \\
PLT-F & & 82.00 & 89.00 \\
PDW & $\mathrm{fL}$ & 8.2 & 104 \\
MPV & $\mathrm{fL}$ & 9.7 & 11.3 \\
P-LCR & $\%$ & 18.4 & 31.9 \\
PCT & $\%$ & 0.08 & 0.18 \\
\hline
\end{tabular}

Abbreviations: PLT-I, impedance method of platelet counting; PLT-F, platelet counting with fluorescence; PDW, platelet distribution width; MPV, mean platelet volume; $P-L C R$, platelet large cell ratio; PCT, plateletcrit.
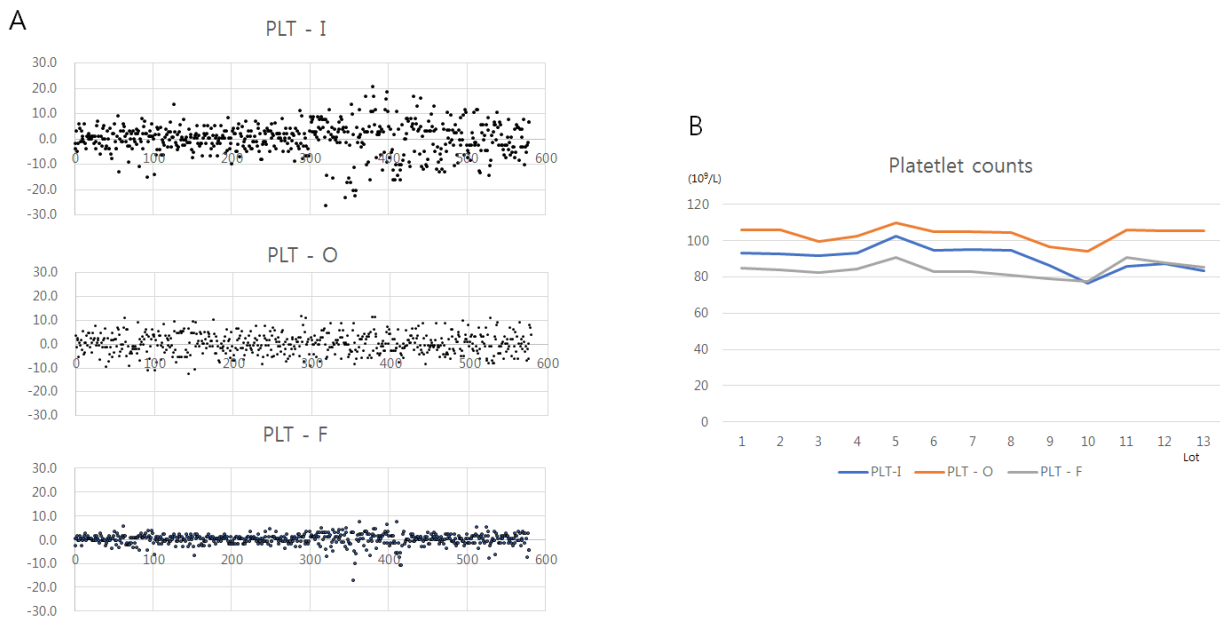

Figure 4. The comparison of dot plots (A) and graph (B) with PLT-I, PLT-O and PLT-F methods. The dot plots represent the difference of total average minus daily data values, the graph shows the mean values of platelet by lot. 

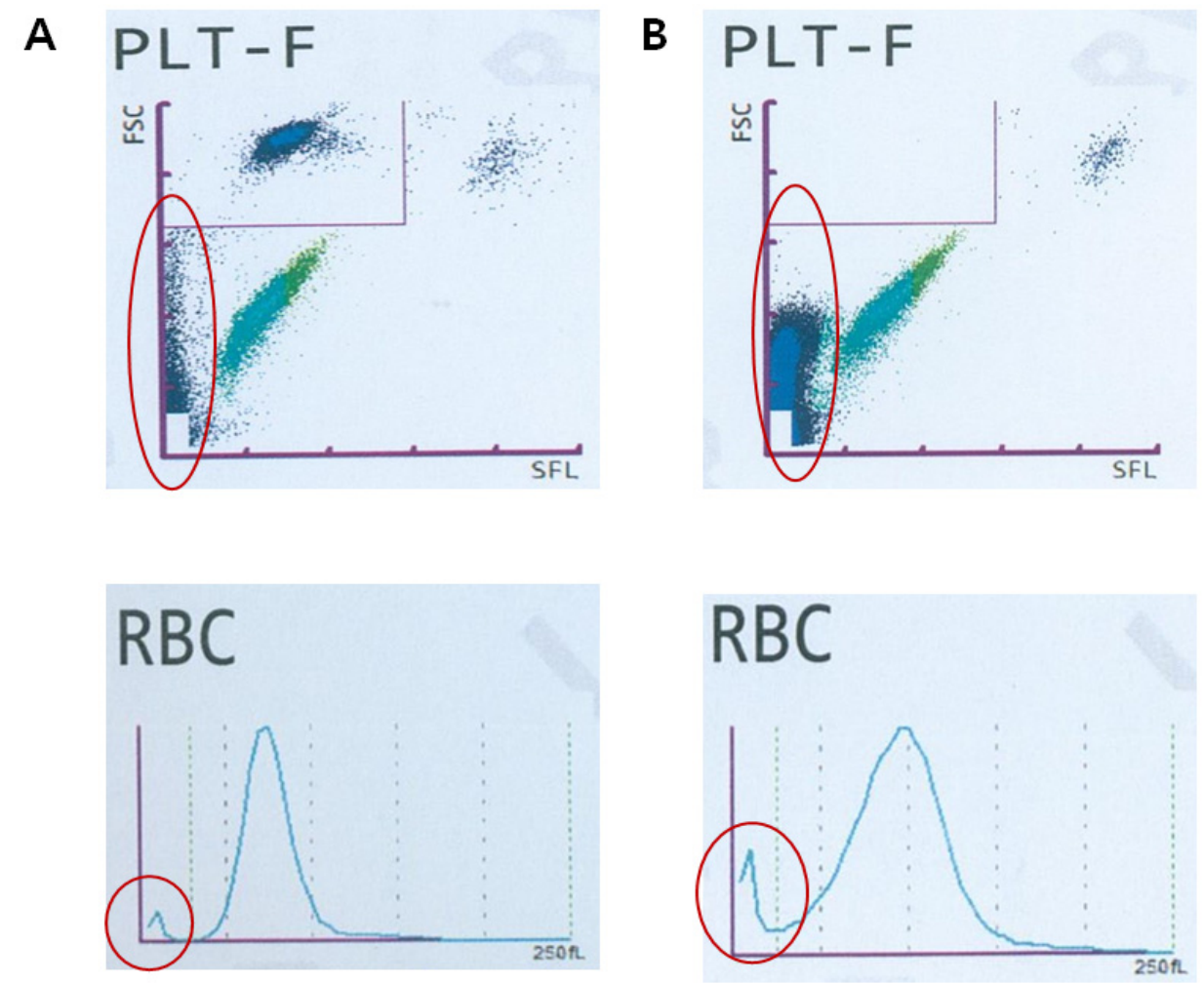

Figure 5. The scattergrams and histograms of XN-9000 hematology analyzer demonstrating the difference using information forward scattered light (FSC) and side fluorescence intensity (SFL) after hemolysis. (A) before hemolysis, (B) after hemolysis. The red line circle is believed to be where cell fragments are plotted.

\section{DISCUSSION}

The first generation automated platelet counters could not distinguish platelets from other particles of the same size using electric impedance. To resolve this problem, second generation automated platelet count systems, based on flow cytometry, were developed over 10 years ago. The next generation automatic platelet count method, PLT-F, which is based on fluorescent labeling and flow cytometry. Different from the PLT-I method, the PLT-O and PLT-F methods use fluorescent staining of RNA content combined with flow cytometry technique for analysis. Dyes used in the PLT-O and PLT-F systems are polymethine and oxazine, respectively. The membranes of the platelets are perforated by the lysing reagent, but they remain largely intact during this process. Subsequently, the fluorescence marker specifically labels the RNA inside the platelets, avoiding interferences with other cells or fragments of similar size. Recently investigators had examined that the results of PLT-F channel were good correlation with CD41/CD61 immune flow cytometry method $[11,12]$.

Now the impedance platelet count is widely used in many clinical laboratories for routine patient testing [13-16]. However, the use of both impedance and optical methods in automated hematology analyzers results in platelet measurement deviations that might be caused by interference from large platelets or cell fragments of a size similar to platelets and determination of the number of platelets is hampered by a certain degree of variation and deviation especially the low-range counts. Due to these problem, fluorescent platelet counts cannot be used routinely in every case because of the higher cost and extended volume, as compared to PLT-I. The PLT-F channel analyses a 5-fold larger sample volume of the aspirated sample compared to the PLT-I channel. In this study, we confirmed that the CV of PLT-F was smaller and more stable compared to PLT-I and PLT-O.

This study confirmed that PLT-F on XN-9000 is a preferred method for low platelet counting especially the hemolyzed samples. The PLT-F method was superior to the impedance method in low counting samples. However, as we mentioned above, PLT-F cannot be used routinely in every case. When the counts of platelet are low level, we suggest that the action is needed to recount 
and confirm with PLT-F system.

And P-LCR vales were significantly higher in hemolyzed samples with PLT-F in this study. However, due to using the QC materials instead of patients' samples, this paper could not provide a comprehensive result. These results indicate that a more accurate estimation of platelet counts can be achieved using the PLT-F method than the PLT-I method. We suggest that P-LCR is a new parameter in assessing samples when the specimen is suspected of hemolysis and deterioration. The use of PLT-F system improves confidence of results in low platelets samples in routine hematology laboratory. The further investigation is needed to establish the relationship with P-LCR and hemolysis using human blood specimens. The findings of this study may provide useful information regarding the quality control of platelet counts in the clinical laboratory.

\section{요 약}

임상검사실에서의 혈소판 수 계산은 지혈이상의 진단과 치 료에 필수적이며, 혈소판 수가 적은 경우 혈소판 수혈이 필요하 고 항암치료 후 혈소판 수 경과를 모니터링하는데 매우 중요하 다. 정도관리는 환자결과를 내보내기 전에 검사실에서 오류를 줄이고 교정하는 과정이며 분절된 적혈구는 혈소판과 크기가 비슷하여 혈소판 수 계산에 영향을 미친다. 검사실에서 내부정 도관리low $\mathrm{QC}$ 물질이 $2 \mathrm{SD}$ 를 벗어난 것을 경험하였고, 지금까 지 용혈과 혈소판 지표들과의 관계에 대해 밝혀진 것이 충분하 지 않아 연구를 시작하였다. 이에 본 연구에서는 XN CHECK low level QC물질을 이용해 PLT-I, PLT-O, PLT-F 방법간의 혈 소판수치를 비교하였으며, 용혈검체를 만들어 5 가지 혈소판지 표들에 대해 비교분석 하였다. 그 결과PLT-F방법에서 CV값이 가장 적게 나타났으며, 용혈검체에서 P-LCR 수치가 $18.4 \%$ 에 서 $31.9 \%$ 로 증가함을 보였다. 이 연구를 통해 혈소판 수치가 낮 은 경우는 PLT-F방법으로 하는 것이 더 정확하며, 검체가 용혈 이나 변질이 의심되는 경우 이를 평가할 때 P-LCR을 새로운 지 표로 제시하고 있으며, 사람 혈액검체를 이용한 추후 연구가 더 필요할 것이라고 사료된다.

\section{Acknowledgements: None}

Conflict of interest: None

Author's information (Position): Shim MJ ${ }^{1}$, Professor; Lee
$\mathrm{HA}^{2}$, M.T.

\section{REFERENCES}

1. Segal HC, Briggs C, Kunka S, Casbard A, Harrison P, Machin SJ, et al. Accuracy of platelet counting haematology analyzers in severe thrombocytopenia and potential impact on platelet transfusion. Br J Haematol. 2005;128:520-525.

2. Saliba RM, Komanduri KV, Giralt S, de Souza J, Patah P, Oran B, et al. Leukemia burden delays lymphocyte and platelet recovery after allo-SCT for AML. Bone Marrow Transplant. 2009;43: 685-692.

3. Briggs C, Harrison P, Machin SJ. Continuing developments with the automated platelet count. Int J Lab Hematol. 2007;29: 77-91.

4. Briggs C, Longair I, Kumar P, Singh D, Machin SJ. Performance evaluation of Sysmex haematology XN modular system. J Clin Pathol. 2012;65:1024-1030.

5. Briggs C, Kunka S, Machin SJ. The most accurate platelet count on the Sysmex XE-2100: optical or impedance? Clin Lab Haematol. 2004;26:157-158.

6. Schoorl M, Schoorl M, Oomes J, van Pelt J. New fluorescent method (PLT-F) on Sysmex XN2000 hematology analyzer achieved higher accuracy in low platelet counting. Am J Clin Pathol. 2013;140:495-499.

7. Niethammer AG and Forman EN. Use of the platelet histogram maximum in evaluating thrombocytopenia. Am J Hematol. 1999;60:19-23.

8. Park Y, Schoene N, Harris W. Mean platelet volume as an indicator of platelet activation: methodological issues. Platelets. 2002;13:301-306.

9. Wada A, Takagi Y, Kono M, Morikawa T. Accuracy of a new platelet count system (PLTOF) depends on the staining property of its reagents. PLoS One. 2015;10:1-13.

10. Grotto H, Noronha J. Platelet larger cell ratio (P-LCR) in patients with dyslipidemia. Clin Lab Haematol. 2004;26:347-349.

11. Briggs C, Harrison P, Grant D, Staves J, MacHin SJ. New quantitative parameters on a recently introduced automated blood cell counter: the XE2100. Clin Lab Haematol. 2000;22:345-350.

12. Tanaka Y, Tanaka Y, Gondo K, Maryki Y, Kondo T, Asai S, et al. Performance evaluation of platelet counting by novel fluorescent dye staining in the $\mathrm{XN}$-series automated hematology analyzers. J Clin Pathol. 2014;28:341-348.

13. Tantanate C, Khowawisetsut L, Pattanapanyasat K. Performance evaluation of automated impedance and optical fluorescence platelet counts compared with international reference method in patients with thalassemia. Arch Pathol Lab Med. 2017; 141:830-836.

14. Zandecki M, Genevieve F, Gerard J, Godon A. Spurious counts and sprious results on haematology analyzers. Int J Lab Hematol. 2007;29:4-20.

15. Siegenthaler M, Spertini O. Images in clinical medicine: spurious platelet count. N Engl J Med. 2006;354:1936.

16. Tantanate C. Spuriously high platelet counts by various automated hematology analyzers in patient with disseminated intravascular coagulation. Clin Chem Lab Med. 2015;53:257-259. 